\title{
Global Radicalization and the San Bernardino Attack-Evolving Extremist U.S. Domestic Threat
}

\author{
Thomas M. Fitzpatrick \\ Husson University, Bangor, ME, USA
}

\begin{abstract}
The focus of this paper is the process of radicalization of the San Bernardino attackers and their source of inspiration and affiliations. The literature on the pathway to terrorism and jihad appears to agree that pathways and triggers are varied and many with no clear set of traits that one can identify to predict individual paths to jihadism, in short, it is an idiosyncratic process. So, while the psychological profiling of high risk jihadist individuals has yet to be fruitful, the psycho/sociological behaviors associated with jihadism appear to offer greater promise. This paper will divide into four actions: their pathway to radicalization, affiliations/relations, source of inspiration, and the conclusion.
\end{abstract}

Keywords: San Bernadino, attack, Islamic terrorism, jihad, radicalization

\section{Pathways to Radicalization}

According to some family and friends, this couple offered few signals that they had begun the journey down the path of radicalization, jihad, shahid or martyrdom, and terrorist violence. It should be noted that this is a relatively common posture adopted by family members during the post attack phase under the pressure and embarrassment of investigations by government and the media; it may be accurate or it may be a posture to avoid accusations of complicity and legal liability. In assessing the pathways of these two individuals born on two separate continents, yet each converging on the path to violent jihad with one another in San Bernardino on Dec. 2nd 2015, "As early as the end of 2013 [they] were talking to each other about jihad and martyrdom before they became engaged and married and were living in the US", Comey told the senators, adding that "investigators did not yet know whether their online courtship had been arranged by any sort of foreign terror organization or if it developed naturally on its own” (Vice Dec, 2015, p. 1). Director Comey did note that their individual paths of radicalization had begun years before they met, "the two were inspired by foreign terror groups that likely predated the rise of ISIS ... but these two killers were starting to radicalize toward martyrdom and jihad as early as 2013” (Vice Dec, 2015, p. 1).

Below is a time line offering a perspective on the individual radicalization of Farook and Tashfeen before they met and after they married. One could make the case that Farook and his neighbor constituted a terrorist "cell” as they had planned an attack in 2012 but disengaged when the press reported the arrests in Los Angles of jihadist terrorists. Farook's marriage to Tashfeen brought together two like-minded individuals who acted as one, much like the brothers Tamerland Tsarnev and Jokar Tsarnev of the Boston Bombing. The author would characterize these terrorists as "lone wolves". 

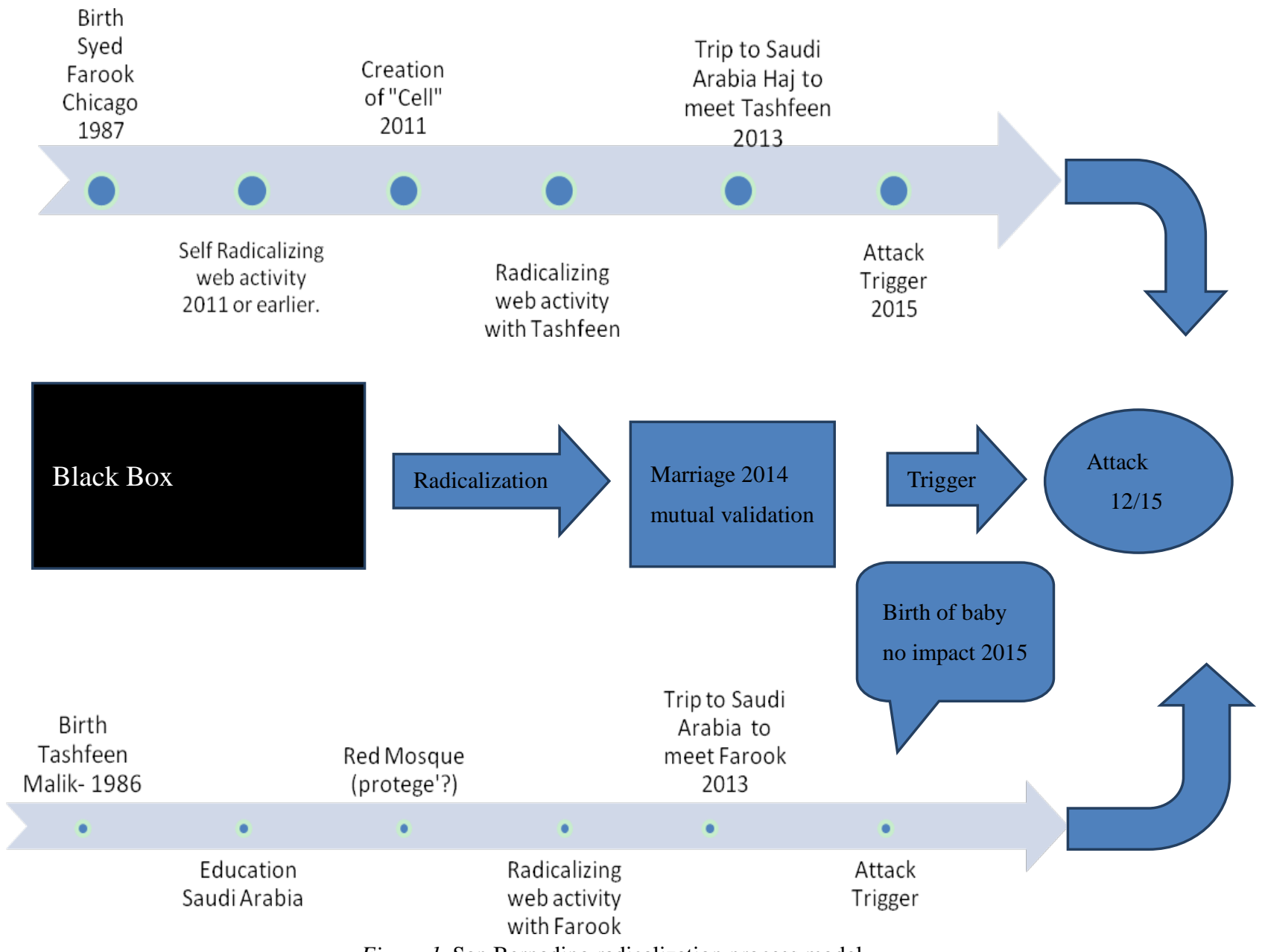

Figure 1. San Bernadino radicalization process model.

Two continents apart Farook and Tashfeen embarked on their individual paths of radicalization independently; she in Pakistan and Saudi Arabia and he in San Bernardino and until their rampage nothing truly brought them on to the radar of law enforcement or intelligence agencies. They were as the literature suggests ordinary or "normal” Farook is a middle class government employee and Taskfeen attended a fundamentalist girl's school and was enrolled at a School of Pharmacy in Pakistan. Six months before their attack and their physical de-radicalization, they had become parents and left an infant orphaned as they pursued violent jihad and martyrdom. The concept of the "Black Box" has been coined as metaphor for thought process that leads to radicalization, extremism, violent jihadism, and shahid or martyrdom. So far, no one has been able to crack the "Black Box" and decipher its contents to make predicting terrorist behavior possible. One would think that a six-month-old baby would have acted as a cognitive opening to break the process of radicalization to violent jihad and cause Farook and Tashfeen to disengage psychologically and physically from jihad, but alas no.

Categorizing a social profile of the attackers employing Nesser's terrorist typology is difficult if not impossible based upon the information currently available as the investigation is only two months old (Peter, 2006). 

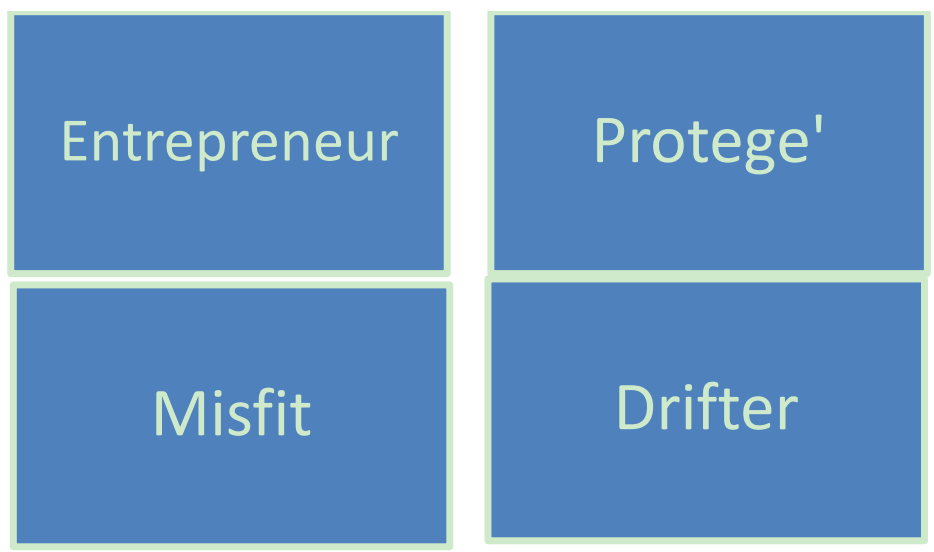

Figure 2. Nesser's Terrorist Typology.

In the case of "lone wolves", you are likely to find a combination of these typologies presented to one degree or another. Farook due to conflict identity issues could be characterized as a misfit not genuinely accepting the culture and country of his birth. He had some of the characteristics of an entrepreneur as he attracted a recruit to his "cell" and conceived and planned an attack. Tashfeen has a longer history of radical Islamic grooming and she was educated at a fundamentalist girl's school in Saudi Arabia (the historic birthplace of Salafism and Wahabism) and then returned to Pakistan to attend college and affiliated with Pakistan's notorious Red Mosque. It would be difficult to place her in the misfit or drifter category, so it appears that she falls somewhere in the range of Protégé' to entrepreneur.

Entrepreneurs, "who embrace Islamism through intellectual processes and proactively recruit and socialize their cadre. Protégés, "who are similar to the entrepreneurs and appear to become radicalized through a combination of loyalty to the entrepreneur and intellectually justified activism”. Misfits, "who typically join the group due to a combination of loyalty to friends and to cope with personal problems such as troubled backgrounds and/or criminal records", drifters, "whose dominant motivations for joining appear to relate to social commitments, elements of youth rebellion, or a search for adventure”. (Peter, 2006, p. 4)

As one reviews the literature on the process of radicalization, extremism, jihadism, and finally violent terrorism, it becomes apparent that the path is genuinely an individual one where the process and the pace to becoming a jihadist terrorist do not fit a timetable or template, in short, it is unique to the individual, time, and place. For some, it takes years and others months maybe sufficient. "However, there does not appear to be a fixed sequence of 'radicalization stages' that an individual travels through which ultimately results in the decision to resort to terrorist violence" (Huffman, 2015). It is evident from the literature that that no clear template of psycho/social motivation can be laid over an individual to provide confirmation that they are on the path of radicalization, extremism, and ultimately violent jihadist behavior.

The literature suggests that an incomplete "identity" or as it is termed "fragmented psychosocial identify" is the precursor or cognitive opening that can launch an individual on their individual pathway to radicalization.

Quintan Wiktorowicz's theory of a cognitive opening “cognitive openings” which render individuals “more receptive to the possibility of alternative views and perspectives. If the individual is exposed to a compelling ideology during this period of relative openness to new ideas, the potential for radicalization is increased. (Huffman, 2011, p. 11)

There are however behaviors that would suggest that an individual might be a candidate for further scrutiny and perhaps observation; are they affiliating with individuals or mosques that would be considered extreme, travel 
patterns domestic, and international, manner of dress and demeanor, social media consumed, direct statements indicating militancy, acquisition of the means (guns/weapons), and any statements of admiration/support of terrorist events. The over-arching challenge for government agencies both law enforcement and intelligence is the limited resources available to them and the exponential growth of potential "lone wolves". In one congressional interview, FBI Director James Comey was quoted as saying that "it takes up to 19 agents to monitor a single individual 24 hours a day" (James Comey, 2016 Fox News).

One anectodal footnote is that in the aftermath of a "lone wolf" jihadist attack almost invariably the individual has held up red flags about their support or belief in jihad or support of their perceived oppression struggle, whether you are talking about San Bernadino, Fort Hood, Boston Bombing, or the attempted attack in Dallas. These signals are missed or ignored and never reported to authorities for consideration. The neighbors of Farook and Tashfeen were more afraid of being considered politically incorrect (Islamaphobic) than they were concerned about the unusual or suspicious behavior they observed.

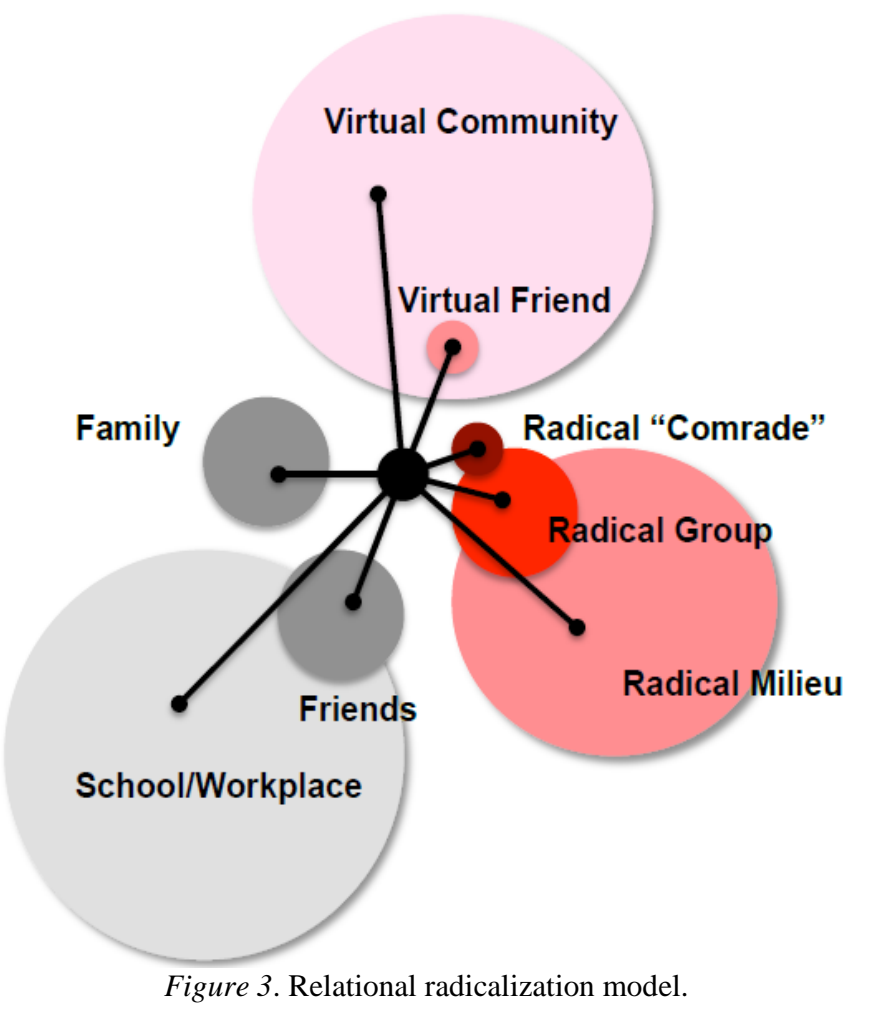

Malthaner and Lindekilde (2015, p. 11) offered a non-linear view of the radicalization of lone wolves or what might be misnamed as self-radicalizers with their paper "Analyzing Pathways of Lone-Actor Radicalization: A Relational Approach”. In reviewing the elements of the model above, they appear to serve effectively in a forensic assessment of the relational pathways to violent radicalization for Farook and Tashfeen.

\section{School/Mosque:}

Tashfeen Malik is known to have studied in Multan but US officials now say she is linked to the notorious Red Mosque in Islamabad, the capital of Pakistan. Its chief cleric has publicly said he supports ISIS US officials told their Pakistani counterparts today that Tashfeen Malik was linked to the country's most notorious mosque. (Hussain, 2012, p. 1) 
Radical Comrade: Tashfeen and Farook met on line and began their courtship and radicalization affirmational process via the web. Later, they would meet in Saudi Arabia and subsequently marry. Their union is not only marriage but also political ideology that gave them a powerful "mutual validation" of their jihadist values.

Radical Group/Friend: This is harder to determine but they did pledge allegiance to ISIS (Islamic State of Iraq and Levant) and Farook had created his own "cell” of sorts with his recently converted neighbor Enrique Marquez purchasing the guns in 2011 used in the attack and together planning an earlier attack in 2012 they disengaged from out of fear of arrest. Marquez indicated that they had formulated plans to attack Riverside Community College in 2012 but abandoned the plans after another group was arrested in LA.

Family: Farook's mother lived with them and it is hard to imagine that she did not have some inkling or see the preparations before the attack. Father claims ignorance while other family members indicated that they saw a change in Farook's appearance and intensity of his belief system. Tashfeen's father was said to be heartbroken but she attended a fundamentalist school in Saudi Arabia and the radical Red Mosque in Pakistan, so within the context of a Radical Milieu that her changes could go unnoticed is dubious.

Workplace: For Farook may have served as a "trigger" event with it being noted that he argued with a Jewish co-worker a few weeks before the attack.

Colleague Kuuleme Stephen said that when she had called Thalasinos at work he told her he was having a heated discussion with Farook about Islam who had told him Islam was a peaceful religion and that Americans do not understand Islam.

But it should be noted that attack was well-planned and materials gathered years, months, and weeks in advance in preparation for a jihadist attack.

Virtual Community: Malik pledged her allegiance to the leader of ISIS in a Facebook post, according to three U.S. officials familiar with the shootings. FBI investigators found evidence of private communications between Tashfeen and Farook on the Internet and FBI Director Comey indicated that both were active were "consuming poison on the Internet and both had become radicalized "before they started courting or dating each other online and before the emergence of ISIL” (Wikipedia, 2015).

Political sociologists offer a theory of cognitive openings based on identity conflict or perhaps crisis that occurs for second generation Muslims attempting to adapt or reconcile their duality of being Muslim and born in the West. "Political sociology suggests that Islamist radicalization in Europe occurs when second and third generation Muslim immigrants experience a 'conflict of identity' resulting from the dissolution of traditional identities and communities through processes of globalization and migration” (Huffman, 2010, p. 14). It occurs to the author that individuals with conflict identity or recent converts to Islam may feel a stronger need to demonstrate the strength of their commitment to their beliefs, group identity, or heritage through extremism and violence that well-adjusted individuals do not.

\section{San Bernadino Attack Timeline}

The San Bernardino attack spanned seconds, minutes, and hours. The duration of the shooting was minutes. The first patrol units arrived in minutes. More than 10 hours passed between the report of shots fired and the building being cleared for investigators. The coordination and rapid response taken within a matter of minutes are commendable. Stopping the threat within a matter of hours is admirable. The aftermath and recovery take time. 
Investigations and recovery continued after the attack. Which time intervals were most significant and how can incident commanders, SWAT (Special Weapons and Tactics) personnel, and other officers understand and manage time as an incident unfolds?

San Bernardino attack timeline (as cited in the critical incident response review, Cotter, 2016) as follows:

- 10:58 a.m. First report of five rounds heard in the 1,300 block of South Waterman Avenue.

- 10:59 a.m. Report of three suspects armed with assault rifles wearing all black clothing.

- 11:00 a.m. Two patrol units dispatched.

- 11:04 a.m. First unit arrives on scene (Lieutenant Mike Madden).

- 11:06 a.m. Lieutenant, detective, motor, and patrol officer form a contact team and make entry.

- 11:09 a.m. San Bernardino Police Department SWAT arrives with 12 operators and a tactical medic (six more arrive later).

- 11:15 a.m. Triage area established at South Park Center and Waterman Avenue.

- 11:17 a.m. First floor secured. Patient evacuation to triage area.

- 11:26 a.m. Roof cleared.

- 11:30 a.m. Directed Probation to set up containment area for those exiting Building \#1.

- 11:31 a.m. Secondary sweep of building.

- 11:33 a.m. possible device found on 2nd floor office (roller luggage bag out of place).

- 11:46 a.m. San Bernardino County Sheriff's Department EOD on scene.

- 11:51 a.m. EOD determined device was suspicious.

- 11:56 a.m. SBCSD Special Enforcement Division cleared Building \#1.

- 12:24 p.m. Inland Valley Regional SWAT team to 2nd floor of Building \#1 to clear and evacuate.

- 12:38 p.m. Unified tactical command post established with SBPD, SBCSD, and Inland Valley SWAT team. The FBI joined later but was on standby to assist if needed at other locations.

- 1:42 p.m. Robot deployed to X-ray suspicious package.

- 2:22 p.m. X-ray complete, device deemed safe.

- 2:35 p.m. SBCSD completes search and evacuation of Buildings \#1 and \#2.

- 3:02 p.m. Redlands Police Department in 100mph pursuit of unrelated stolen car that terminates half a mile from command post.

- 3:02:17 p.m. SBPD narcotic unit flagged down Redlands Police Department sergeant.

- 3:08:19 p.m. SBPD narcotics and Redlands Police Department following suspect vehicle eastbound between San Bernardino Avenue and Richardson.

- 3:08:43 p.m. Shots fired while officers attempt to stop suspect vehicle.

- 3:09 p.m. Suspect in custody from the Redlands Police Department stolen vehicle pursuit (orange show road and arrowhead).

- 3:09:22 p.m. Suspects stop and gun battle ensues (1795 East San Bernardino Avenue).

- 3:12 p.m. Bearcat (armored vehicle) requested.

- 3:12:57 p.m. *** Officer Down *** Narcotics officer shot in left thigh with 0.223 round at corner of Shedden and San Bernardino.

- 3:14:53 p.m. Shooting stops.

- $3: 19$ p.m. SED units searching for potential third suspect seen running from the area of the SUV.

- 3:19 p.m. Bearcat on scene. 
- 5:08 p.m. Explosive devices located on 1st floor primary building.

- 7:36 p.m. Device removed for destruction.

- 7:54 p.m. Device \#1 detonated/rendered safe.

- 8:33 p.m. Device \#2 detonated/rendered safe.

- 8:37 p.m. Device \#3 detonated/rendered safe.

- 9:29 p.m. Building clear and released to investigators

\section{Conclusion}

The topic of radicalization, extremism, and violent jihadist expression will likely remain a hot topic for the foreseeable future with each new event providing additional fuel to research and theorizing on the reasons why an individual chooses the pathway to violence and martyrdom. In much the same way that human criminality has some markers or red flags that are observable; it might suggest that the "recurrent mechanisms" of Islamic radicalization and extremist jihadism might serve as benchmarks for addressing it. So, what would a checklist of recurrent mechanisms look like; born or converted to Islam, activity on Jihadist websites, affiliation and contact with Jihadists domestically, internationally or virtually, travel to Jihadist hotspots, change in behaviors and physical appearance, extremist pronouncements, declaring allegiance to an Islamic terrorist organization and finally participation in a terrorist attack. All of these characteristics quickly fall into place forensically in the aftermath of a jihadist attack, but prior to the attack assembling these elements into a cogent and coherent picture is a daunting if not impossible task to achieve at a $100 \%$ success rate.

\section{References}

Armey, G. (2016). Islamist terrorism: Getting to grips with the post jihad world. UK Independent. Retrieved from https://www.independent.co.uk/arts-entertainment/books/features/islamist-terrorism-getting-to-grips-with-the-post-jihad-worl d-a6812696.html

Cotter, H. R. (2016). Lessons from the San Bernardino terror attack timeline. Retrieved from https://www.policeone.com/police-products/body-armor/articles/245726006-Lessons-from-the-San-Bernardino-terror-attacktimeline/

Eric, T., \& Asif, S. (2015). HuffPost politics, San Bernardino shooters radicalized at least 2 years ago. FBI Directors Says, 12/09/15.

Huffman, A. (2011). Homegrown terrorism in the United States: Comparing radicalization trajectories in Britain and America. Retrieved from https://repository.library.georgetown.edu/bitstream/handle/10822/553516/huffmanAlexia.pdf?sequence=1

Krisnadev, C. (2015). The long radicalization of the San Bernadino shooters. The Atlantic. Retrieved from https://www.theatlantic.com/national/archive/2015/12/san-bernardino-shooting/419223/

Malthaner, S., \& Lindekinlde, L. (2015). Analyzing Pathways of Lone-Actor Radicalization: A Relational Approach. Retrieved from http://dpsa.dk/papers/LindekildeMalthaner_Analyzing\%20Pathways\%20of\%20Lone\%20Actor\%20Radicalization_19.10.2015.pdf

Mark, B., \& Sari, H. (2015). San Bernadino shooter spent years steeped in extremism before attack. The Washington Post, $12 / 18 / 15$

Nesser, P. (2016). Dynamics of jihadist cell structures in Europe/UK. Retrieved from https://www.academia.edu/5439184/Dynamics_of_Jihadist_cell_structures_in_Europe_and_UK

Shakman, P. D. (2015). US News. The Evolving Extremist Threat, 12/07/15.

WikiPedia. (2015). San Bernadino attack. Retrieved from https://en.wikipedia.org/wiki/2015_San_Bernardino_attack 2015 